Jejaring Administrasi Publik, Vol. 13, No. 1, 2021, hal 35-48

\title{
Paradigma dan Dimensi Strategi Ketahanan Pangan Indonesia
}

\section{Paradigm and Dimensions of Indonesia's Food Security Strategy}

\author{
Andi Rachman Salasa \\ Badan Kebijakan Fiskal, Kementerian Keuangan \\ E-mail: andi.rachman91@ui.ac.id; andisalasa@gmail.com
}

\begin{abstract}
Indonesia is known as an agrarian country with abundant natural resources, but this condition does not necessarily make the people of Indonesia able to access food easily and cheaply. Indonesia now is actually known as a food importing country. Food security is very important because it is estimated that Indonesia's current population of 267 million is projected to continue to increase to 319 million in 2045. The Indonesian government must be able to formulate a national food policy that can improve food security. The food policy includes the availability of food supplies in good quantity and quality as well as the affordability of food prices by the community and safe for consumption. The government must begin to see that food security will be realized if the three main dimensions of food security are: (i) availability; (ii) access (accessibility); and (iii) affordability (affordability) by a person (family) can be fulfilled. The government must also be able to integrate policies on food security and food price stability with other national development policies such as macroeconomic policies through economic growth and equity and poverty alleviation.
\end{abstract}

Keywords: paradigm, food security, dimension, strategy

\begin{abstract}
Abstrak
Indonesia dikenal sebagai Negara Agraris dengan sumber daya alam yang berlimpah, namun kondisi ini tidak serta merta menjadikan masyarakat Indonesia dapat mengakses pangan dengan mudah dan murah. Indonesia saat ini ini justru dikenal sebagai negara pengimpor pangan. Ketahanan pangan menjadi sangat penting karena diperkirakan jumlah penduduk yang Indonesia yang saat ini sebesar 267 juta jiwa diproyeksikan akan terus meningkat menjadi 319 juta jiwa di tahun 2045 mendatang. Pemerintah Indonesia harus dapat merumuskan kebijakan pangan nasional yang dapat meningkatkan ketahanan pangan. Kebijakan pangan tersebut meliputi ketersedian pasokan pangan dalam kuantitas dan kualitas yang baik serta keterjangkauan harga pangan oleh masyarakat dan aman untuk dikonsumsi. Pemerintah harus mulai melihat bahwa ketahanan pangan akan terwujud apabila tiga dimensi utama dari ketahanan pangan yaitu: (i) ketersediaan (availability); (ii) akses (accessability); dan (iii) keterjangkauan (affordability) oleh seseorang (keluarga) dapat terpenuhi. Pemerintah juga harus mampu mengintegrasikan kebijakan ketahanan pangan dan stabilitas
\end{abstract}




\section{Salasa: " Paradigma dan Dimensi Strategi Ketahanan Pangan Indonesia"}

harga pangan dengan kebijakan pembangunan nasional lainnya semacam kebijakan ekonomi makro melalui pertumbuhan dan pemerataan ekonomi dan pengentasan kemiskinan.

Kata Kunci: Paradigma, ketahanan pangan, dimensi, strategi

\section{Pendahuluan}

Indonesia dikenal sebagai Negara Agraris dengan sumber daya alam yang berlimpah, namun kondisi ini tidak serta merta menjadikan masyarakat Indonesia dapat mengakses pangan dengan mudah dan murah. Indonesia dalam dasarwarsa ini justru dikenal sebagai negara pengimpor pangan. Pada tahun 2015 Indonesia mengimpor beras sebanyak kurang lebih 2,2 juta ton dengan nilai berkisar pada USD 1 Milyar (BPS 2020). Data impor BPS menyatakan bahwa Indonesia aktif menjadi pengimpor beras dari tahun 2000 dengan jumlah yang bervariasi dengan nilai jutaan Unite Stated Dollar.

Tabel 1

Luas Panen, Produksi dan Produktivitas dan Impor Beras Indonesia

\begin{tabular}{|l|c|c|c|c|}
\hline & 2012 & 2013 & 2014 & 2015 \\
\hline Luas Panen (ha) & 8.127 .264 & 8.128 .499 & 8.111 .593 & 8.087 .393 \\
\hline Produktivitas (ku/ha) & 51,36 & 51,52 & 51,35 & 53,41 \\
\hline Produksi (ton) & 69.056 .126 & 71.279 .709 & 70.846 .465 & 75.397 .841 \\
\hline Impor beras (ton) & 810.327 & 472.664 & 844.163 & 861.601 \\
\hline Impor beras (USD) & 942.623 & 246.002 & 388.178 & 351.602 \\
\hline
\end{tabular}

Sumber: BPS 2020

Ketahanan pangan sendiri selalu menjadi isu dalam pembangunan nasional indonesia. dari jaman orde lama, orde baru hingga sekarang. Ketahanan pangan selalu menjadi salah satu tujuan utama yang ingin dicapai oleh pemerintah Indonesia (Rachman \& Ariani, 2002). Peranan sektor pertanian sebagai penghasil pangan di Indonesia menjadi sangat penting dalam memenuhi kebutuhan pangan masyarakat Indonesia (Purwaningsih, 2008). Ketahanan pangan menjadi sangat penting karena diperkirakan jumlah penduduk yang Indonesia yang saat ini sebesar 267 juta jiwa diproyeksikan akan terus meningkat menjadi 319 juta jiwa di tahun 2045 mendatang (BPS, 2020). Pemerintah Indonesia harus dapat merumuskan kebijakan pangan nasional yang dapat meningkatkan ketahanan pangan. Kebijakan pangan tersebut meliputi ketersedian pasokan pangan dalam kuantitas dan kualitas yang baik serta keterjangkauan harga pangan oleh masyarakat dan aman untuk dikonsumsi (Rachman \& Ariani, 2002). Timmer (2004) berpendapat bahwa ketahanan pangan sangat terkait dengan 
kemampuan pemerintah untuk menjaga harga bahan makanan dan kemampuan suatu negara untuk memproduksi bahan pangan yang cukup untuk seluruh masyarakat dengan harga yang terjangkau. Timmer (1997) berargumen bahwa pemenuhan kebutuhan pangan adalah hal yang sangat penting bagi suatu negara, tidak ada negara yang mampu mempertahankan pertumbuhan ekonomi tanpa lebih dahulu menyelesaikan masalah pangan.

Kebijakan pemerintah dalam mewujudkan ketahanan pangan ditunjukkan dalam peran aktif pemerintah dalam membangun sitem ketahanan pangan yang baik dan berdaya tahan (resilience). Keberhasilan kebijakan pemerintah dalam mewujudkan ketahanan pangan akan sangat bergantung pada paradigma atau pendekatan yang dipilih dalam melihat konteks ketahanan pangan dan mengintegrasikan kebijakan ketahanan pangan dengan kebijakan pembangunan nasional lainnya semisal kebijakan pengentasan kemiskinan dan kebijakan makro perekonomian (Simanjutak, 2007). Saat ini tampaknya potensi produksi pangan sebagai bagian kebijakan dari ketahanan pangan Indonesia tidak didayagunakan secara optimal. Peranan sektor pertanian dalam Produk Domestik Bruto (PDB) Indonesia terutama di kategori tanaman pangan tampak tidak begitu besar, PDB pertanian indonesia hanya mampu mencatat sebesar 12,84\% dari total PDB di tahun 2020 (BPS, 2020). Namun demikian, sektor pertanian masih menjadi sektor terbesar yang menyerap tenaga kerja sebesar 27,33\% di tahun 2019 (BPS, 2020). Bila permasalahan pangan ini tidak mendapatkan perhatian khusus dari pemerintah, bukan tidak mungkin peran pertanian dalam perekonomian negara akan semakin kecil. Bahkan mungkin di masa depan, Indonesia dapat masuk ke dalam kondisi krisis pangan yang dapat mempengaruhi stabilitas nasional (Rachman et al, 2005).

\section{Paradigma dan Strategi Ketahanan Pangan}

Undang-Undang No. 18 tahun 2012 tentang pangan pada pasal satu memberikan definisi tentang ketahanan pangan sebagai "kondisi terpenuhinya pangan bagi negara sampai dengan perseorangan, yang tercermin dari tersedianya pangan yang cukup baik jumlah maupun mutunya, aman, beragam, bergizi, merata dan terjangkau serta tidak bertentangan dengan agama, keyakinan dan budaya masyarakat, untuk dapat hidup sehat, aktif dan produktif secara berkelanjutan". Sedangkan Badan Pangan Dunia (FAO) memberikan definisi ketahanan pangan sebagai kondisi di mana tersedianya pangan yang memenuhi kebutuhan setiap orang baik dari segi mutu pangan dan jumlah pangan pada setiap saat untuk hidup sehat aktif dan produktif (Simatupang 2007). Berdasarkan definisi-definisi tersebut, terdapat tiga dimensi utama dari ketahanan pangan yaitu: (i) ketersediaan 


\section{Salasa: " Paradigma dan Dimensi Strategi Ketahanan Pangan Indonesia"}

(availability); (ii) akses (accessability); dan (iii) keterjangkauan (affordability) (Syaukat 2011).

Peljor dan Minot (2010) menyatakan bahwa kemandirian/swasembada pangan (food sufficiency) merupakan kondisi di mana suatu negara dapat memenuhi kebutuhan konsumsi pangan masyarakatnya yang berasal dari produksi dalam negeri daripada dengan membeli atau melakukan impor dari negara lain. Badan Pangan Dunia (FAO) menyebutkan bahwa kemandirian/swasembada pangan merupakan strategi yang ampuh dalam mewujudkan ketahanan pangan (Syaukat 2011). Dari definisi tersebut, dapat dikatakan bahwa untuk mewujudkan ketahanan pangan, suatu negara harus berusaha mewujudkan kemandirian/swasembada pangan terlebih dahulu dan langkah melakukan impor pangan merupakan langkah antisipatif yang hanya ditempuh apabila pemerintah merasa aksesabilitas harga pangan dan jumlah ketersediaan pangan di pasar dirasa dalam kondisi mengkhawatirkan. Syaukat (2011) menyatakan ketahanan pangan nasional terjadi ketika terjadi keseimbangan antara penawaran dan permintaan (supply and demand) akan kebutuhan pangan nasional pada tingkat harga dan jumlah ketersediaan di pasar yang dapat diakses oleh masyarakat. Dari pernyataan ini dapat diketahui, ketahanan pangan sangat dipengaruhi oleh aksesabilitas harga dan kesediaan pangan di masyarakat

Kebijakan ketahanan pangan Indonesia semenjak orde baru tidak banyak berubah hingga saat ini yaitu dengan pendekatan penyediaan pangan (Food Avaibility Approach) atau FAA (Simatupang, 2007). Paradigma FAA menyatakan bahwa ketahanan pangan suatu negara ditentukan oleh kemampuan negara untuk menyediakan makanan pokok yang cukup untuk seluruh warga negara dan kurang memperhatikan aspek distribusi dan akses terhadap pangan. Pendekatan FAA dalam ketahanan pangan beranggapan apabila pasokan pangan tersedia maka para pedagang akan menyalurkan pangan tersebut secara efisien dan harga pangan akan tetap stabil dalam tingkat harga yang dapat dijangkai oleh seluruh masyarakat. Pendekatan FAA dalam mewujudkan ketahan pangan menyebabkan perumusan kebijakan pemerintah dalam pangan selama ini berfokus pada keterjangkauan harga dan swasembada pangan. Hal ini mengakibatkan pemerintah Indonesia selalu fokus pada strategi jangka pendek dan menengah berupa stabilisasi harga komoditas beras selaku komoditi pangan utama di Indonesia dan strategi jangka panjang berupa pewujudan swasembada beras (Simatupang, 2007). Dalam upaya menuju swasembada pangan, selama bertahun-tahun pemerintah Indonesia mengeluarkan kebijakan intensifikasi pertanian seperti pemberian subsidi pupuk, subdisi benih, pembangunan infrastruktur pertanian, peningkatan kualitas sdm petani, pemberian kredit pertanian dan lain-lain yang berfokus pada peningkatan produksi 
pangan nasional dan berusaha menjaga harga pangan di masyarakat dengan membiayai cadangan pangan, membuat sistem jaringan cadangan pangan melalui Bulog selaku lumbung pangan nasional dan mengeluarkan Harga Eceran Tertinggi (HET) pada komoditas beras (Purwaningsih, 2008).

Tabel 2

Anggaran Program Kedaulatan Pangan APBN 2019

(Triliun rupiah)

\begin{tabular}{|c|c|c|}
\hline \multirow{2}{*}{ Uraian } & 2018 & 2019 \\
\hline & APBN & APBN \\
\hline $\begin{array}{l}\text { I. Kementerian Negara/Lembaga } \\
\text { 1. Kementerian Pertanian } \\
\text { 2. Kementerian Kelautan Perikanan } \\
\text { 3. Kementerian Pekerjaan Umum dan Perumahan Rakyat } \\
\text { 4. Kementerian Sosial }\end{array}$ & $\begin{array}{r}59,3 \\
23,8 \\
4,3 \\
10,3 \\
20,8\end{array}$ & $\begin{array}{r}56,8 \\
21,7 \\
2,8 \\
11,5 \\
20,8\end{array}$ \\
\hline $\begin{array}{l}\text { II. Non K/L } \\
\text { 1. Subsidi } \\
\text { a.I Subsidi Pupuk } \\
\text { 2. Belanja Lain-lain } \\
\text { III. Transfer ke Daerah (DAK) } \\
\text { 1. DAK Irigasi } \\
\text { 2. DAK Pertanian }\end{array}$ & $\begin{array}{r}33,5 \\
28,5 \\
28,5 \\
5,0 \\
5,9 \\
4,2 \\
1,7\end{array}$ & $\begin{array}{r}34,5 \\
29,5 \\
29,5 \\
5,0 \\
4,9 \\
3,0 \\
1,9\end{array}$ \\
\hline Total & 98,7 & 96,2 \\
\hline
\end{tabular}

Sumber: Kementerian keuangan RI, 2019

Hasil kebijakan ketahan pangan nasional terutama swasembada pangan komoditas beras cukup berhasil di waktu periode orde baru tahun 90-an, namun tidak berlangsung lama. Setelah periode tersebut produksi pangan indonesia kesulitan dalam mencapai swasembada pangan dan menjaga harga pangan tetap terjangkau (Prasetiyani \& Widiyanti (2013). Penyebab tidak tercapainya swasembada pangan antara lain dikarenakan gagal panen raya, berkurangnya lahan pertanian akibat alih fungsi lahan, inflasi, perubahan iklim dan lain sebagainya. Hal ini menyebabkan pemerintah Indonesia harus terus mengimpor bahan pangan terutama beras untuk mencukupi kebutuhan pangan dan menjaga tingkat harga bahan pangan agar tetap terjangkau oleh masyarakat (lihat tabel 1).

Sen (1989) menyatakan bahwa ketahanan pangan tidak mensyaratkan suatu negara untuk melakukan swasembada pangan karena swasembada pangan akan sangat tergantung pada sumber daya yang dimiliki. Suatu negara bisa menghasilkan dan mengekspor suatu 


\section{Salasa: " Paradigma dan Dimensi Strategi Ketahanan Pangan Indonesia"}

komoditas yang bernilai ekonomi tinggi semisal barang industri maupun tambang, dan membeli komoditas pangan di pasar internasional. Sebaliknya negara yang mampu melakukan swasembada pangan pada level nasional, dijumpai masyarakatnya ada yang masuk kategori rawan pangan karena ada hambatan akses dan distribusi dari pangan itu sendiri. Sen (1981) meyakini bahwa kerawanan pangan dan kelaparan yang terjadi dalam suatu masyarakat bukan hanya soal produksi dan ketersediaan semata. Berdasarkan kasus kelaparan yang terjadi di benua Afrika dan India, kelaparan terjadi karena ketiadaaan akses atas pangan (pendapatan per kapita suatu wilayah tidak mencukupi untuk mengakses bahan pangan), bahkan ketika produksi pangan sedang melimpah akibat panen. Oleh karena itu produksi pangan yang cukup melalui swasembada pangan bukan penentu tunggal dalam ketahanan pangan, melainkan hanya salah satu faktor di samping ketersediaan pangan yang terjangkau oleh masyarakat.

\section{Analisis Kegagalan Strategi Ketahanan Pangan}

Strategi ketahanan pangan pemerintah yang selama ini mengejar kemandirian swasembada (sufficiency) dan stabilisasi harga pangan dengan paradigma FAA ternyata menimbulkan implikasi mendasar pada penyusunan strategi dan kebijakan produksi pangan. Simatupang (200\&) menyatakan setidaknya ada tiga implikasi dari strategi swasembada pangan pemerintah Indonesia yang diturunkan kedalam kebijakan yang ada selama ini, yaitu: 1) pembangunan pertanian diprioritaskan pada pencapaian swasembada beras sebagai komoditas pokok nasional, 2) kebijakan pemerintah berfokus pada peningkatan pertumbuhan produksi beras agar ketersediaan pangan terjaga setiap saat dan 3) harga beras di tingkat petani harus serendah mungkin dan pada tingkat harga terjangkau. Strategi pemerintah dalam ketahanan pangan dengan menggunakan paradigma ini banyak mendapatkan tantangan dari para peneliti karena tidak mampu menjelaskan fenomena kerawanan pangan maupun insiden kelaparan yang tetap terjadi di banyak negara (Sen, 2008). Paradigma FAA yang dianut Pemerintah Indonesia selama ini dinilai memiliki kelemahan karena pada kenyataannya, kondisi swasembada pangan khususnya beras Indonesia yang dicapai pada orde baru tidak dapat menjamin seluruh orang (keluarga) dalam masyarakat memperoleh pangan yang dibutuhkannya dengan mudah dan murah (Nouval et.al, 2010).

Simatupang (1999) memberikan penjelasan mengapa strategi paradigma FAA atau Swasembada/Kemandirian Pangan yang dilakukan pemerintah selama ini memiliki kelemahan secara konseptual, yaitu: 1) tidaklah benar bahwa strategi dalam jangka pendek menjaga stabilitas harga adalah kebenaran mutlak. Dalam prakteknya daya beli masyarakat 
akan pangan tidak hanya ditentukan dengan harga yang terjangkau, namun juga oleh tingkat pendapatan masyarakat. Sebagai contoh kerawanan pangan yang terjadi pada waktu krisis moneter 1998 kebih disebabkan karena inflasi yang mengakibatkan daya beli masyarakat menjadi rendahm padahal pasokan pangan beras cukup di pasaran. 2) tidak benar anggapan adanya kondisi pasar yang benar-benar sempurna dimana ketika supply meningkat maka harga akan turun. Pada krisis moneter tahun 1998, harga pangan beras meningkat walaupun pasokan melimpah. 3) anggapan produksi domestik pangan merupakan sumber pengadaan pangan yang paling handal perlu dipertanyakan, hal ini dikarenakan kemungkinan terjadinya gagal panen di domestik oleh karena suatu hal, sehingga tetap mengandalkan produksi pangan domestik akan menjadi sangat mahal sehingga pemerintah terpaksa mengambil langkah impor untuk menjaga pasokan pangan sekaligus menekan harga pangan 4) pandangan tentang harga beras harus terjangkau atau murah di level petani cenderung tidak memperhatikan kesejahteraan petani sehingga banyak membuat petani terperangkap dalam kemiskinan dan kerawanan pangan dan 5) pemerintah hanya memperhatikan ketahanan pangan nasional namun kurang memperhatikan faktor distribusi sehingga dapat menimbulkan kerawanan pangan lokal. Sebagai contoh walaupun selama ini persediaan pangan di level nasional mencukupi namun kejadian rawan pangan tetap terjadi di daerah rawan pangan seperti Papua Barat dan Nusa Tenggara Timur akibat persedian pangan di tingkat lokal yang tidak mencukupi dikarenakan produksi padi yang memang sedikit dalam provinsi tersebut (Tabel 3).

Tabel 3

Produksi Padi Berdasarkan Provinsi

\begin{tabular}{|l|l|l|l|l|}
\hline \multirow{2}{*}{ Provinsi } & \multicolumn{4}{c|}{ Produksi (Ton) } \\
\cline { 2 - 5 } & \multicolumn{4}{c|}{ Padi } \\
\cline { 2 - 5 } & \multicolumn{1}{|c|}{$\mathbf{2 0 1 2}$} & \multicolumn{1}{|c|}{$\mathbf{2 0 1 3}$} & \multicolumn{1}{c|}{$\mathbf{2 0 1 4}$} & \multicolumn{1}{c|}{$\mathbf{2 0 1 5}$} \\
\hline Aceh & 1788738 & 1956940 & 1820062 & 2331046 \\
\hline Sumatera Utara & 3715514 & 3727249 & 3631039 & 4044829 \\
\hline Sumatera Barat & 2368390 & 2430384 & 2519020 & 2550609 \\
\hline Riau & 512152 & 434144 & 385475 & 393917 \\
\hline Jambi & 625164 & 664535 & 664720 & 541486 \\
\hline Sumatera Selatan & 3295247 & 3676723 & 3670435 & 4247922 \\
\hline Bengkulu & 581910 & 622832 & 593194 & 578654 \\
\hline Lampung & 3101455 & 3207002 & 3320064 & 3641895 \\
\hline
\end{tabular}


Salasa: " Paradigma dan Dimensi Strategi Ketahanan Pangan Indonesia"

\begin{tabular}{|c|c|c|c|c|}
\hline Kep. Bangka Belitung & 22395 & 28480 & 23481 & 27068 \\
\hline Kep. Riau & 1323 & 1370 & 1403 & 959 \\
\hline Dki Jakarta & 11044 & 10268 & 7541 & 6361 \\
\hline Jawa Barat & 11271861 & 12083162 & 11644899 & 11373144 \\
\hline Jawa Tengah & 10232934 & 10344816 & 9648104 & 11301422 \\
\hline Di Yogyakarta & 946224 & 921824 & 919573 & 945136 \\
\hline Jawa Timur & 12198707 & 12049342 & 12397049 & 13154967 \\
\hline Banten & 1865893 & 2083608 & 2045883 & 2188996 \\
\hline Bali & 865553 & 882092 & 857944 & 853710 \\
\hline Nusa Tenggara Barat & 2114231 & 2193698 & 2116637 & 2417392 \\
\hline Nusa Tenggara Timur & 698566 & 729666 & 825728 & 948088 \\
\hline Kalimantan Barat & 1300100 & 1441876 & 1372695 & 1275707 \\
\hline Kalimantan Tengah & 755507 & 812652 & 838207 & 893202 \\
\hline Kalimantan Selatan & 2086221 & 2031029 & 2094590 & 2140276 \\
\hline Kalimantan Timur & 561959 & 439439 & 426567 & 408782 \\
\hline Kalimantan Utara & - & 124724 & 115620 & 112102 \\
\hline Sulawesi Utara & 615062 & 638373 & 637927 & 674169 \\
\hline Sulawesi Tengah & 1024316 & 1031364 & 1022054 & 1015368 \\
\hline Sulawesi Selatan & 5003011 & 5035830 & 5426097 & 5471806 \\
\hline Sulawesi Tenggara & 516291 & 561361 & 657617 & 660720 \\
\hline Gorontalo & 245786 & 295913 & 314704 & 331220 \\
\hline Sulawesi Barat & 412338 & 445030 & 449621 & 461844 \\
\hline Maluku & 84271 & 101835 & 102761 & 117791 \\
\hline Maluku Utara & 65686 & 72445 & 72074 & 75265 \\
\hline Papua Barat & 30245 & 29912 & 27665 & 30219 \\
\hline Papua & 138032 & 169791 & 196015 & 181769 \\
\hline Indonesia & 69056126 & 71279709 & 70846465 & 75397841 \\
\hline
\end{tabular}

Sumber: BPS (2020) 


\section{Jejaring Administrasi Publik, Vol. 13, No. 1, 2021, hal 35-48}

Kesalahan paradigma dan strategi Pemerintah Indonesia dalam ketahanan pangan selama ini didukung dengan bukti-bukti empiris antara lain: 1) Banyaknya petani di pedesaan yang masih hidup dibawah garis kemiskinan dan ancaman kerawanan pangan, 2) Insinden kerawanan pangan masih terjadi di tingkat lokal khusunya pada daerah yang bukan penghasil beras surplus walaupun persediaan pangan di level nasional atau aggregate mencukupi 3) fokus pangan pemerintah pada komditi beras membuat komoditi pangan lokal lain semakin ditinggalkan semacam jagung, umbi-umbian, sagu dan lain-lain. 4) Swasembada pangan yang diraih dengan susah payah tenyata tidak mampu bertahan (sustain) dibuktikan dengan masih meingkatnya rata-rata impor beras setiap tahunnya, 5) Sistem ketahanan pangan yang dianut Pemerintah Indonesia selama ini terbukti tidak mampu meredam dampak krisis ekonomi yang berakibat pada munculnya krisis pangan, contioh pada krisis moneter tahun 1998, 6) Intensifikasi usaha tani untuk meningkatkan produksi pangan beras melalui penggunaan pupuk kimia dan pestisida menyebabkan lahan pertanian rentan terhadap serangan hama dan gagal panen sehingga produksi pangan beras menjadi sulit diprediksi. 7) Kebijakan ketahanan pangan pemerintah Indonesia yang bersifat top-down cenderung tidak dapat diterapkan di lapangan. Sebagai contoh adalah kebijakan lumbung desa dan koperasi unit desa tidak berhasil diterapkan karena tidak sesuai dengan kebutuhan lokal daerah, dan 8) Kebijakan pemerintah dalam mewujudkan ketahanan pangan menyebabkan beban pada anggaran negara melalui pemberian subsidi dan proteksi yang cenderung salah sasaran dan tidak bermanfaat.

Purwaningsih (2008) memberikan gambaran umum permasalahan ketahanan pangan Indonesia adalah penyediaan, distribusi dan konsumsi pangan. Penyediaan pangan melalui peningkatan kapasitas produksi domestik dihadapkan pada semakin terbatasnya lahan pertanian yang dalam jangka panjang mengakibatkan penurunan kapasitas produksi (Tabel.1, luas panen). Hal ini disebabkan oleh 1) terjadinya konversi lahan pertanian ke non pertanian, 2) menurunnnya kualitas dan kesuburan lahan pertanian akibat kerusakan lingkungan dampak dari intensifikasi pertanian dengan penggunaan pupuk dan pestisida, 3) kurang memadainya sarana prasarana irigasi pertanian dan 4) semakin terbatasnya sumber daya air akibat persaingan dengan sektor industri dan pemukiman. Distribusi pangan memiliki permasalahan berupa: 1) prasarana dan sarana distribusi antar wilayah Indonesia khususnya wilayah timur masih belum memadai dan menjangkau daerah pelosok sehingga memicu biaya distribusi yang berakibat pada kenaikan harga pangan dan mengurangi daya beli masyarakat. 2) Kelembagaan pemerintah (Bulog dan Kementerian Pertanian) belum mampu menbentuk sistem distribusi yang baik sehingga pada masa panen pasokan pangan melimpah 


\section{Salasa: " Paradigma dan Dimensi Strategi Ketahanan Pangan Indonesia"}

ke pasar sehingga harga turun dan mengurangi keuntungan petani dan sebaliknya disaat panen tidak berhasil, harga meningkat signifikan sehingga mengurangi keterjangkauan masyarakat. Sedangkan permasalahan konsumsi pangan adalah belum semua keluarga/individu (rumah tangga) khususnya masyarakat miskin memiliki akses pada pangan yang cukup.

Terkait dengan impor pangan, pada era globalisasi dan pasar bebas saat ini, hampir tidak ada negara yang menutup diri dari perdagangan global dan berusaha untuk memenuhi seluruh kebutuhan negaranya secara domestik (self sufficiency). Banyak negara yang melakukan perdagangan global fokus pada produksi produk unggulan negara tersebut dan mengekspor kelebihan produksinya kepada negara lain dan disaat yang sama memilih untuk memperoleh kebutuhan yang tidak dapat dipenuhi olleh produksi domestik melalui impor. Food and Agriculture Organization (FAO) Perserikatan Bangsa-Bangsa telah mengungkapkan bahwa ketahanan pangan bukanlah masalah dari satu negara saja namun merupakan permasalahan global. Dengan paradigma ini strategi kebijakan pangan negaranegara dunia berubah dari swasembada pangan menjadi swadaya pangan. Pada swasembada pangan, seluruh produksi pangan nasional dipenuhi melalui produksi pangan domestik. Di era globalisasi seperti ini swadaya pangan dipandang sebagai upaya memenuhi kebutuhan pangan nasonal baik dari produksi domestik maupun impor, untuk itu seharusnya pemerintah Indonesia tidak perlu alergi atau anti kepada impor pangan asalkan tidak berlebihan dan tetap bertumpu pada produksi domestik, dengan demikian impor pangan dianggap sebagai langkah pendamping produksi pangan domestik. Kedepannya pengelolaan impor pangan disaat produksi domestik turun dan sebaliknya melakukan ekspor pangan disaat produksi domestik melebihi kebutuhan nasional perlu dilakukan untuk menjaga harga stabilitas pangan di pasar.

\section{Kebijakan Strategis Ketahanan Pangan}

Hasil analisis menunjukkan bahwa paradigma dan strategi ketahanan pangan nasional melalui paradigma FAA atau swasembada/kemandirian pangan yang selama ini dilakukan oleh pemerintah Indonesia tidak efektif dan efisien. Pemerintah harus mulai melihat bahwa ketahanan pangan akan terwujud apabila tiga dimensi utama dari ketahanan pangan yaitu: (i) ketersediaan (availability); (ii) akses (accessability); dan (iii) keterjangkauan (affordability) oleh seseorang (keluarga) dapat terpenuhi (Syaukat 2011). Alih-alih fokus pada ketahanan pangan secara makro (agregat atau nasional), pemerintah harus lebih fokus kepada ketahanan pangan di level meso (regional level provinsi dan kabupaten kota) dan mikro (keluarga/individu) dimana ketahanan pangan harus dapat diturunkan dari level 
ketahanan pangan nasional ke ketahanan pangan regional lokal secara berjenjang/hierarki di level propinsi dan ketahananan pangan kabupaten/kota hingga akhirnya pada ketahanan pangan keluarga dan individu (Simatupang, 2007). Setiap tingkatan pemerintah baik pemerintah pusat, pemerintah tingkat provinsi dan pemerintah kabupaten/kota wajib bertanggung jawab terhadap ketahanan pangan daerahnya masing-masing sesuai lingkup tanggung jawabnya berdasarkan jenjang administrasi pemerintahan. Pemerintah juga harus mampu mengintegrasikan kebijakan ketahanan pangan dan stabilitas harga pangan dengan kebijakan pembangunan nasional lainnya semacam kebijakan ekonomi makro melalui pertumbuhan dan pemerataan ekonomi dan pengentasan kemiskinan.

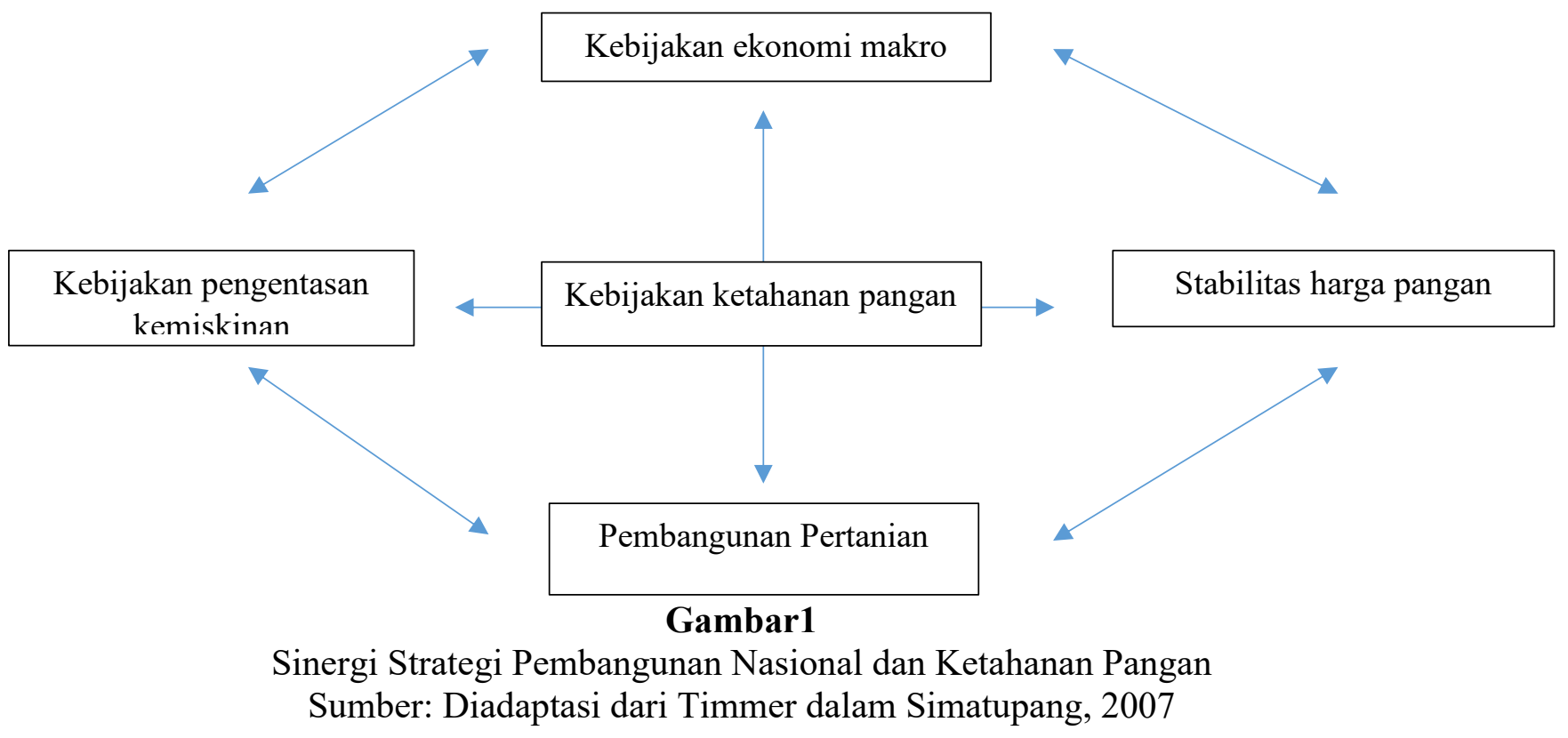

Kebijakan ketahanan pangan melalui peningkatan kapasitas produksi pangan harus berfokus pada 1) peningkatan inovasi dengan perlibatan swasta melalui research dan development di bidang pertanian dan memfasilitasi importasi teknologi pertanian modern, 2) membangun iklim investasi pertanian sehingga menarik pihak swasta, 3) peningkatan kualitas hidup petani dengan berfokus pada pembangunan infrastruktur pertanian dan pedesaan terutama sarana irigasi pertanian, jalan dan listrik perdesaan 4) penataan distribusi pertanian termasuk rantai pasokan pangan (beras dll) dan material pendukung (pupuk, alat pertanian dll), 5) meningkatkan diversifikasi pangan di level lokal (tidak hanya berfokus pada 


\section{Salasa: " Paradigma dan Dimensi Strategi Ketahanan Pangan Indonesia"}

pangan beras), 6) meningkatkan stabilisasi harga produk dengan dengan mengintegrasikan harga produksi domestik dan internasional.

Strategi ketahanan pangan dapat dibagi berdasarkan dimensi waktu periode perencanaan yaitu jangka pendek, jangka menengah dan jangka panjang, serta tingkatan makro, meso dan mikro (tabel. 4).

\section{Tabel 4}

Strategi Ketahanan Pangan

\begin{tabular}{|c|c|c|c|}
\hline & Jangka Pendek & Jangka Menengah & Jangka Panjang \\
\hline $\begin{array}{l}\text { Level Makro } \\
\text { (Nasional) }\end{array}$ & $\begin{array}{l}\text { - Insentif dan } \\
\text { modal } \\
\text { pertanian } \\
\text { - Menjaga stok } \\
\text { pangan }\end{array}$ & $\begin{array}{ll}\text { - } & \text { Litbang } \\
\text { - } & \text { Pertanian } \\
\text { - } & \text { Swasta } \\
\text { - } & \text { Stabilisasi } \\
\text { harga } \\
\text { pangan }\end{array}$ & 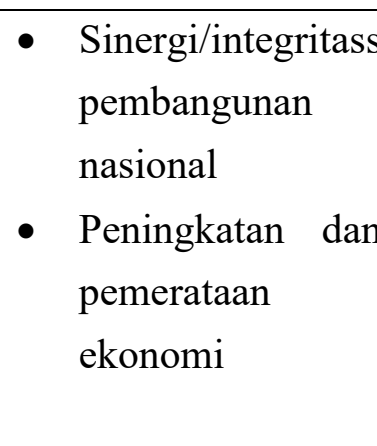 \\
\hline $\begin{array}{l}\text { Level Meso } \\
\text { (Regional lokal) }\end{array}$ & $\begin{array}{ll}\text { - } & \text { Pelatihan } \\
\text { petani } \\
\text { - } \\
\text { Peningkatan } \\
\text { kesejahteraan } \\
\text { petani }\end{array}$ & $\begin{array}{ll}\text { - } & \text { Infrastruktur } \\
\text { - } & \text { Pertanian } \\
\text { distribusi } \\
\text { pertanian }\end{array}$ & 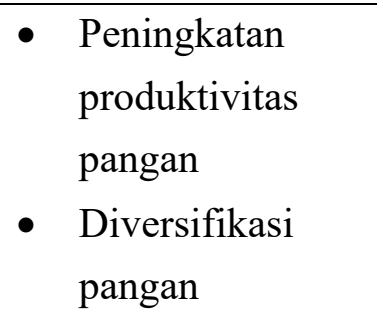 \\
\hline $\begin{array}{l}\text { Level Mikro } \\
\text { (keluarga/individu) }\end{array}$ & $\begin{array}{l}\text { - } \text { Subdisi } \\
\text { pangan } \\
\text { masyarakat } \\
\text { miskin }\end{array}$ & 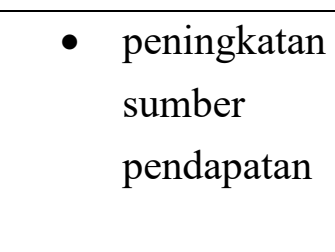 & $\begin{array}{l}\text { - Penghapusan } \\
\text { kemiskinan } \\
\text { - Jaring pengaman } \\
\text { sosial }\end{array}$ \\
\hline
\end{tabular}

Sumber: data hasil olahan peneliti, 2020

\section{Kesimpulan}

Ketahanan pangan merupakan salah satu bagian dari tujuan pembangunan nasional Indonesia. Ketahanan pangan menjadi sangat penting karena diperkirakan jumlah penduduk yang Indonesia yang saat ini sebesar 267 juta jiwa diproyeksikan akan terus meningkat menjadi 319 juta jiwa di tahun 2045 mendatang. Pemerintah harus merumuskan kebijakan pangan nasional yang dapat meningkatkan ketahanan pangan. Kebijakan pangan tersebut meliputi ketersedian pasokan pangan dalam kuantitas dan kualitas yang baik serta keterjangkauan harga pangan oleh masyarakat dan aman untuk dikonsumsi. 


\section{Jejaring Administrasi Publik, Vol. 13, No. 1, 2021, hal 35-48}

Kebijakan ketahanan pangan Indonesia semenjak orde baru tidak banyak berubah hingga saat ini yaitu dengan pendekatan penyediaan pangan (Food Avaibility Approach) atau lebih dikenal dengan swasembada/kemandirian pangan dengan produksi domestik untuk mencukupi kebutuhan pangan nasional. Namun demikian, strategi paradigma FAA atau Swasembada/Kemandirian Pangan yang dilakukan pemerintah selama ini memiliki kelemahan. Dalam upaya mewujudkan ketahanan pangan, Indonesia memliki tiga permasalahan umum yaitu permasalahan penyediaan, distribusi dan konsumsi pangan. Terkait dengan impor pangan, pada era globalisasi dan pasar bebas saat ini, hampir tidak ada negara yang menutup diri dari perdagangan global dan berusaha untuk memenuhi seluruh kebutuhan negaranya secara domestik. Pemerintah Indonesia tidak perlu alergi atau anti kepada impor pangan asalkan tidak berlebihan dan tetap bertumpu pada produksi domestik, impor pangan harus dianggap sebagai langkah pendamping produksi pangan domestik.

Paradigma dan strategi ketahanan pangan nasional melalui paradigma FAA atau swasembada/kemandirian pangan yang selama ini dilakukan oleh pemerintah Indonesia tidak efektif dan efisien. Pemerintah harus mulai melihat bahwa ketahanan pangan akan terwujud apabila tiga dimensi utama dari ketahanan pangan yaitu: (i) ketersediaan (availability); (ii) akses (accessability); dan (iii) keterjangkauan (affordability) oleh seseorang (keluarga) dapat terpenuhi. Pemerintah juga harus mampu mengintegrasikan kebijakan ketahanan pangan dan stabilitas harga pangan dengan kebijakan pembangunan nasional lainnya semacam kebijakan ekonomi makro melalui pertumbuhan dan pemerataan ekonomi dan pengentasan kemiskinan. Usulan Strategi ketahanan pangan dapat dibagi berdasarkan dimensi waktu periode

perencanaan yaitu jangka pendek, jangka menengah dan jangka panjang, serta tingkatan makro, meso dan mikro.

\section{Daftar Pustaka}

BPS (2020). Indikator Pertanian 2017. Jakarta. BPS

BPS (2020). Data Kependudukan 2020. Jakarta. BPS

Nouval F, Zacky, Yoga G dan Kurniawan L (2010) Petaka Politik Pangan di Indonesia (Kebijakan Pangan yang Tidak Memilih Rakyat. Malang. Intrans Publishing. Peljor, N., \& Minot, N. (2010). Food Security and Food Self-Sufficiency in Bhutan. IFRI 


\section{Salasa: " Paradigma dan Dimensi Strategi Ketahanan Pangan Indonesia"}

Prasetyani, I \& Widiyano, D (2013) Strategi Menghadapi Ketahanan Pangan (dilihat dari Kebutuhan dan ketersediaan Pangan) Penduduk Indonesia di Masa Mendatang (Tahun 2015-2040). Jurnal Bumi Indonesia. Vol. 2 No. 2.

Purwaningsih, Y (2008). Ketahanan Pangan: Situasi, Pemrasalahan, Kebijakan dan Pemberdayaan Masyarakat. Jurnal Ekonomi Pembangunan Vol. 9, No. 1, hal. 1-27. Rachman, H \& Ariani, W (2002). Ketahan Pangan: Konsep, Pengukuran dan Strategi. FAE Vol. 20 No.1 hal. 12-24.

Rachman, Benny, Supriyati, dan Supena. (2005). Ekonomi Kelembagaan Sistem Usaha Tani Padi di Indonesia. Jurnal SocioEconomic of Agriculture and Agribusiness, Vol. 5, No. 2, 1-10.

Sen, A (1981). Poverty and Famines: An Essay On Entitlement and Deprivation, Oxford University Press. Oxford.

Sen, A (1989). Food and Freedom. Journal World Development 17 (6): 769-781.

Sen, A (2008). Is Nationalism a Boon or A Curse?. Economic and Political Weekly. 2008;XLIII.

Simatupang, P (1999) .Toward Sustinable Food Security: The World toa New Paradigm. In Simatupang P, Pasaribu, S, Bakri, S and Stinger, B (eds). Indonesia Economic Crisis: Effects on Agriculture and Policy Responses. XASER-CIES. University of Adelaide. Australia P. 1141-167.

Simatupang, P (2007). Analisis Kritis Terhadap Paradigma dan Kerangka Dasar Kebijakan Ketahanan Pangan Nasional. Forum Penelitian Agro Ekonomi. Vol. 25 No. 1, hal. $1-18$

Simatupang, P., \& Maulana, M. (2007). Kaji Ulang Konsep dan Perkembangan Nilai Tukar Petani tahun 2003 - 2006. Jakarta: Pusat Analisis Sosial Ekonomi dan Kebijakan Pertanian Departemen Pertanian.

Syaukat, Y. (2011). Dampak Ekonomi Kebijakan Produksi dan Perdagangan Pangan terhadap Ketahanan Pangan Indonesia. Dalam M. Firdaus, \& dkk, Ekonomi dan Manajemen Ketahanan Pangan. Bogor: IPB Press.

Timmer, C.P. (1997). Farmers and Markets: The Political Economy of New Paradigms. American Journal of Agricultural Economics 79(2):621-627.

Timmer, C.P (2004). Food Security and Economic Growth: An Asian Perspective. H.W and Memorial Lecture. Australian National University. 